\title{
Cytokines from Activated T Cells Induce Normal Endothelial Cells to Acquire the Phenotypic and Functional Features of AIDS-Kaposi's Sarcoma Spindle Cells
}

\author{
Valeria Fiorelli, * Rita Gendelman, * Felipe Samaniego, “ Phillip D. Markham, ${ }^{*}$ and Barbara Ensoli * \\ * Laboratory of Tumor Cell Biology, National Cancer Institute, National Institutes of Health, Bethesda, Maryland 20892; and ${ }^{\ddagger}$ Advanced \\ BioScience Laboratories, Inc., Kensington, Maryland 20895
}

\begin{abstract}
Kaposi's sarcoma (KS) is a proliferative disease of vascular origin particularly frequent in HIV-1-infected homosexual men (AIDS-KS) and characterized by proliferating spindleshaped cells, angiogenesis, and inflammatory cell infiltration. Previous work has suggested that KS spindle cells are of endothelial cell origin and that chronic immune activation via the release of inflammatory cytokines may cooperate with basic fibroblast growth factor (bFGF) and the HIV-1 Tat protein in the induction and progression of AIDS-KS. Here we show that KS spindle cells have features of activated endothelial cells, and that conditioned media from activated $T$ cells, rich in the same inflammatory cytokines increased in HIV-1-infected individuals, induce normal endothelial cells to acquire the phenotypic and functional features of KS cells. These include $(a)$ acquisition of a similar pattern of cell surface antigen expression; $(b)$ similar proliferative response to bFGF; (c) induction of the responsiveness to the mitogenic effect of extracellular HIV-1 Tat protein that is now able to promote the G1-S transition of endothelial cell cycle; and $(d)$ induction in nude mice of vascular lesions closely resembling early $\mathrm{KS}$ as well as the lesions induced by inoculation of $\mathrm{KS}$ cells. These results suggest that chronic immune activation, via release of inflammatory cytokines, may play a role in the induction of KS. (J. Clin. Invest. 1995. 95:1723-1734.) Key words: FVIIIRA - HIV-1 Tat protein - bFGF • endothelial cell cycle • inflammatory cytokines $\cdot$ AIDS

\section{Introduction}

Kaposi's sarcoma (KS) ${ }^{1}$ is a proliferative disease of vascular origin particularly frequent in HIV-1 infected homosexual and

Address correspondence to Barbara Ensoli, Laboratory of Tumor Cell Biology, Bldg. 37, Rm. 6A09, National Cancer Institute, National Institutes of Health, 37 Convent Dr MSC 4255, Bethesda, MD 20892-4255. Phone: 301-402-0442; FAX: 301-496-8394. 1994.

Received for publication 7 June 1994 and in revised form 27 October

1. Abbreviations used in this paper: APAAP, alkaline phosphatase antialkaline phosphatase; bFGF, basic fibroblast growth factor; $\mathrm{CHX}$, cycloheximide; CM, conditioned media; ECGS, endothelial cell growth supplement; ELAM-1, endothelial leucocyte adhesion molecule-1; FN, fibronectin; HTLV, human T cell leukemia/lymphotropic virus; HUVE, human umbilical vein endothelial; ICAM-1, intercellular cell adhesion molecule-1; KS, Kaposi's sarcoma; TBS, Tris-buffered solution; TCM, conditioned media from activated T cells; VCAM-1, vascular cell adhesion molecule-1; VN, vitronectin.

The Journal of Clinical Investigation, Inc.

Volume 95, April 1995, 1723-1734 bisexual men (1-5). The very early stage of $\mathrm{KS}$ is characterized by the presence of activated endothelial cells, angiogenesis, inflammatory cell infiltration, and by the presence of spindleshaped cells of vascular origin which, in time, become the predominant cell phenotype $(1,6-9)$. These features resemble granulation tissue suggesting that $\mathrm{KS}$ begins as an inflammatory process mediated by cytokines $(10,11)$. Inflammatory cytokines (IL-1, IL-6, tumor necrosis factor [TNF], $\gamma$-IFN) are increased in HIV-1-infected individuals (12-18). Homosexuals men are subjected to a variety of sexually transmitted infections (4) and other antigenic stimuli (19) either preceding or accompanying HIV-1 infection, and often show signs of immune activation (20-22). Consequently, they may have increased levels of inflammatory cytokines early during HIV-1 infection. Increased levels of TNF $\alpha$, IL-6 and oncostatin M have been detected in skin lesions of KS $(23,24)$. In addition, $\mathrm{KS}$ can arise prior to any $\mathrm{T}$ cell deficiency (25-27). Further, the administration of TNF $\alpha$ or $\gamma$ IFN to AIDS-KS patients was reported to enhance the progression of $\mathrm{KS}(28,29)$. These findings suggested that chronic immune activation, rather than immunodeficiency, via release of inflammatory cytokines, may play a role in the induction of $\mathrm{KS}(10,11)$.

In previous studies we have shown that conditioned media (CM) from activated T cells (PBMC or enriched T cells) or human $\mathrm{T}$ cell leukemic/lymphotropic virus (HTLV) types I or II-transformed T cell lines (TCM) contain the same inflammatory cytokines found elevated in HIV-1-infected individuals (10, 14-18). Also, TCM have been used to establish longterm cultures of spindle cells from KS lesions of AIDS-patients (AIDS-KS cells) (30). When inoculated in nude mice, AIDS$\mathrm{KS}$ cells induce vascular lesions of mouse cell origin closely resembling early KS in humans (KS-like lesions) (31). These lesions are mediated by cytokines produced by AIDS-KS cells and among them, basic fibroblast growth factor (bFGF), a potent angiogenic factor (32), appears to play a major role (33$35)$. bFGF is also found expressed in spindle cells of both AIDS-KS and classical KS lesions $(35,36)$ and its expression and release are upregulated by inflammatory cytokines or TCM $(37,38,38 \mathrm{a})$. Other studies indicated that KS cells proliferate in response to extracellular HIV-1 Tat protein, a viral product released by $T$ cells during acute infection $(39,40)$ and found present in AIDS-KS lesions (35). Extracellular Tat also induces the adhesion, migration and invasion of KS cells $(35,41,42)$. These effects are, at least partially, mediated by the RGD region of Tat interacting with the integrins $\alpha_{5} \beta_{1}$ and $\alpha_{\mathrm{v}} \beta_{3}$, the receptors for fibronectin (FN) and vitronectin (VN) (41). These integrins are upregulated during angiogenesis induced by bFGF or inflammatory cytokines (43) and are found expressed in vessels and spindle cells of AIDS-KS lesions (35). In addition, bFGF and Tat synergize in inducing in mice lesions closely resembling early human KS (35). All together these observations suggested 
that inflammatory cytokines, bFGF and Tat may cooperate in the development of KS in HIV-1-infected individuals.

It has been suggested that the spindle cells of $\mathrm{KS}$ are of vascular origin and probably of endothelial cell lineage $(9,44-$ 49). However, cultured or in situ KS spindle cells have been reported to express only some endothelial cell markers. In addition, normal endothelial cells have a different morphology, show a proliferative response to $b F G F$ in vitro much higher than KS spindle cells, produce little or no bFGF, do not proliferate in response to exogenous Tat protein, and do not induce KS-like lesions in mice. However, when exposed to CM from activated $\mathrm{T}$ cells, normal endothelial cells acquire a spindle cell morphology indistinguishable from that of $\mathrm{KS}$ cells (10), produce and release bFGF $(37,38,38 \mathrm{a})$ express higher levels of the $\alpha_{5} \beta_{1}$ and $\alpha_{\mathrm{v}} \beta_{3}$ integrins (41), and become responsive to the effects of extracellular Tat $(10,41,42)$. These observations suggested that inflammatory cytokines may represent an initiating factor in $\mathrm{KS}$ pathogenesis and that the spindle cells of $\mathrm{KS}$ may be "activated" endothelial cells. To verify this hypothesis, we investigated whether cultured KS spindle cells express endothelial specific cell markers and whether cytokines produced by activated $\mathrm{T}$ cells could induce normal endothelial cells to acquire the phenotypic and functional features of KS spindle cells.

The results indicate that cultured KS spindle cells are of endothelial cell origin and express the same markers found in the spindle cells in vivo. Inflammatory cytokines induce normal endothelial cells to acquire a pattern of cell surface markers closely resembling that of KS spindle cells, to acquire a proliferative responsiveness to bFGF and Tat which is similar to that of $\mathrm{KS}$ cells, and to induce KS-like lesions in nude mice.

\section{Methods}

Preparation of CM from activated T cells (TCM). CM were prepared from HTLV-II-infected/transformed (nonvirus producing) $\mathrm{CD}^{+}{ }^{+} \mathrm{T}$ cells as previously described $(10,30)$. These $\mathrm{CM}$ contain the same inflammatory cytokines normally produced by mitogen-activated peripheral blood lymphocytes or enriched $\mathrm{T}$ cells from normal donors and at similar average concentration (10), but do not contain viral proteins. These include: IL- $1 \alpha(0.1-1 \mathrm{ng} / \mathrm{ml}), \mathrm{IL}-1 \beta(1-10 \mathrm{ng} / \mathrm{ml}), \mathrm{IL}-2(<0.1$ $\mathrm{ng} / \mathrm{ml})$, IL-6 (10-40 ng/ml), TNF- $\alpha(0.1-1 \mathrm{ng} / \mathrm{ml})$, TNF- $\beta(<100$ $\mathrm{pg} / \mathrm{ml}$ ), granulocyte-macrophage colony stimulating factor (GM-CSF) $(0.1-1 \mathrm{ng} / \mathrm{ml})$, Oncostatin M $(0.5-1 \mu \mathrm{g} / \mathrm{ml})$ and $\gamma$-IFN $(100-200$ $\mathrm{pg} / \mathrm{ml}$ ), as determined by ELISA. These values represent a range of concentrations detected in different CM preparations. No bFGF is present in the CM.

Cell cultures. Human umbilical vein endothelial (HUVE) cells (passage 6-10) were cultured on gelatinized flasks in complete medium composed of RPMI 1640, 15\% of fetal bovine serum (FBS), $45 \mu \mathrm{g} /$ $\mathrm{ml}$ of endothelial cell growth supplement (ECGS) and $30 \mu \mathrm{g} / \mathrm{ml}$ of heparin, $1 \%$ nutridoma HU (100× solution) (Boehringer-Mannheim, Indianapolis, IN), $1 \%$ essential amino acids ( $50 \times$ solution) (GIBCO BRL, Gaithersburg, MD), $1 \%$ non-essential amino acids $(100 \times$ solution) (GIBCO), $1 \mathrm{mM}$ of sodium pyruvate (GIBCO), $100 \mathrm{U} / \mathrm{ml}$ penicillin G-sodium, $100 \mu \mathrm{g} / \mathrm{ml}$ streptomycin sulfate, $0.25 \mu \mathrm{g} / \mathrm{ml}$ amphotericin B (GIBCO). Cytokine-treatment was performed by culturing HUVE cells for 5-6 d in the presence of TCM (1:4 dilution). AIDS-KS cells p3-p10 (KS3, KS4, KS6, KS8, KS11 cell strains), derived from pleural effusion of AIDS-KS patients, were established and cultured in TCM as previously described $(30,33)$.

Reagents. ECGS was purchased from Collaborative Biomedical Products (Bedford, MA), bFGF and propidium iodide from BoehringerMannheim, bromodeoxyuridine (BrdU) from Aldrich-Chemical Co. (Milwaukee, WI), anti-BrdU from Becton Dickinson (San Jose, CA), matrigel from Collaborative Biomedical Products, cycloheximide from Calbiochem-Behring (La Jolla, CA) $\left[4,5-{ }^{3} \mathrm{H}(\mathrm{N})\right]$ leucine $60 \mathrm{Ci} / \mathrm{mmol}$, [methyl- ${ }^{3} \mathrm{H}$ ] methionine $72.2 \mathrm{Ci} / \mathrm{mmol}$, [ methyl- ${ }^{3} \mathrm{H}$ ] thymidine $6.7 \mathrm{Ci} /$ mmol and $\left[5,6-{ }^{3} \mathrm{H}\right]$ uridine $40.1 \mathrm{Ci} / \mathrm{mmol}$ were purchased from New England Nuclear (Boston, MA). vWF was measured in cell supernatants by an ELISA kit purchased from American Diagnostica (Greenwich, $\mathrm{CN}$ ). The origin and the specificity of the antibodies utilized for the staining of HUVE and AIDS-KS cells is reported in Table I. Recombinant HIV-1 Tat protein from the HIV-1 $1_{\text {IIB }}$ isolate was expressed in $E$. coli, isolated and purified to homogeneity as previously described (40). The procedures for maintaining biologically active Tat and preventing oxidation, and for testing its activity have been described elsewhere (40).

Immunohistochemistry. Immunostaining was performed by both alkaline phosphatase anti-alkaline phosphatase (APAAP) method or by double indirect immunoperoxidase method using cytospin preparations of cells or cells grown for $24 \mathrm{~h}$ on gelatin-coated slides. Briefly, slides were fixed in cold acetone for $10^{\prime}$, air dried, washed in Tris-buffered solution (TBS) and incubated with the primary antibody at room temperature for $20 \mathrm{~min}$ (APAAP method) or for $1 \mathrm{~h}$ (immunoperoxidase method). The slides were then rinsed in TBS and incubated at room temperature for $20 \mathrm{~min}$ with rabbit anti-mouse antibody (1:25, Dako, Glostrup, Denmark) or for $1 \mathrm{~h}$ with rabbit anti-mouse peroxidaseconjugated antibodies (1:100; Dako). The slides were washed again in TBS and the APAAP complex (1:25) or swine anti-rabbit peroxidase (1:100) were applied for an additional $20 \mathrm{~min}$ at room temperature. After washing in TBS, both the second and the third steps of the APAAP method were repeated to amplify the reaction. The reaction of the APAAP method was developed with the Fast Red substrate system (Dako) and the peroxidase reaction was developed with 3,3-diaminobenzidine tetrahydrochloride cromogen (Dako). Blocking of nonspecific binding and of endogenous peroxidases was performed for both methods. The percentage of positive cells in duplicate samples for each experiment and in more than five fields per slide was evaluated following counterstaining with Mayer's hematoxylin solution (Sigma Chemical Co., St. Louis, MO).

$\checkmark W F$ detection by ELISA. HUVE and AIDS-KS cells were cultured for $6 \mathrm{~d}$ in the presence or in the absence of TCM as described above. Supernatants from $3 \mathrm{~d}$-culture were centrifuged for $5 \mathrm{~min}$ at $1500 \mathrm{rpm}$ and stored at $-20^{\circ} \mathrm{C}$ until assayed.

$R N A$, protein, and DNA synthesis in response to bFGF or Tat. Quiescent HUVE cells were obtained by culturing cells for $24 \mathrm{~h}$ in the assay medium (complete medium without growth supplements, ECGS and heparin, nutridoma and with only $10 \%$ FBS ) as previously described (50). Cytokine-treated or untreated HUVE cells were trypsinized, washed twice in RPMI 15\% containing FBS, resuspended in assay medium and seeded in 96-well plates (Costar, Cambridge, MA) at 0.8$1 \times 10^{3}$ cells/well. After synchronization, the recombinant proteins (bFGF or Tat, in the absence of heparin) or the protein buffer (PBS$0.1 \%$ BSA, negative control) and $0.5 \mu \mathrm{Ci}\left[{ }^{3} \mathrm{H}\right]$ uridine, $2.5 \mu \mathrm{Ci}\left[{ }^{3} \mathrm{H}\right]-$ methionine/leucine or $1 \mu \mathrm{Ci}\left[{ }^{3} \mathrm{H}\right]$-thymidine were added to the wells in a total volume of $250 \mu \mathrm{l} .10 \mu \mathrm{g} / \mathrm{ml}$ of cycloheximide were added when protein synthesis inhibition assays were performed. Cells were then harvested at different time points $(3,6,12,24,48$, and $72 \mathrm{~h})$ and the cpm of incorporated precursors were determined with a $\beta$ counter (1250 Beta plate from LKB/Pharmacia [Turkv, Finland]). The results are expressed as the percent increase of incorporation of the labeled precursors induced by the growth factors over the basal incorporation obtained with the protein buffer, assumed as $0 \%$. Statistical analysis was performed by using a two-sided unpaired $t$ Test.

Evaluation of cells in S-phase by FACS analysis. Exponentially growing HUVE cells were obtained by plating $1.5-2 \times 10^{5}$ cells/T 75 $\mathrm{cm}^{2}$ flask in complete medium and by culturing them for $72 \mathrm{~h}$ in the absence or in the presence of TCM. Cells were then trypsinized, fixed in cold $70 \%$ ethanol for $30 \mathrm{~min}$ in ice, centrifuged and resuspended in $500 \mu \mathrm{l}$ of the staining solution $(100 \mu \mathrm{g} / \mathrm{ml}$ propidium iodide, $0.1 \%$ Triton X-100, $37 \mu \mathrm{g} / \mathrm{ml}$ EDTA in PBS) and $500 \mu \mathrm{l}$ of RNase (200 U/ $\mathrm{ml}$ ). Nuclei were analyzed by flow cytometry using the Cellfit software (Becton Dickinson). 
Table I. Cell Surface Marker Expression in Untreated and Cytokine-treated HUVE Cells Compared with AIDS-KS Cells

\begin{tabular}{|c|c|c|c|c|}
\hline Antibody & Specificity & HUVE & CT-HUVE & AIDS-KS \\
\hline & & $\%$ & $\%$ & $\%$ \\
\hline FVIII-RA & Endothelial cells; mouse monoclonal, Dako (Glostrup, Denmark) & $60 \pm 6$ & $10 \pm 4$ & NEG \\
\hline EN-4/CD31 & $\begin{array}{l}\text { Endothelial cells, platelets, monocytes, granulocytes, B cells, megakaryocytes; } \\
\text { mouse monoclonal, Monosan (Uden, Netherlands) }\end{array}$ & $86 \pm 7$ & $46 \pm 1$ & NEG \\
\hline EN $7 / 44$ & Endothelial cells; endometrial cells; mouse monoclonal, Amac (Westbrook, ME) & $68 \pm 12$ & $71 \pm 1$ & $60 \pm 16$ \\
\hline H 4-7/33 & $\begin{array}{l}\text { Endothelial cells, various established carcinoma and lymphoblastoid cell lines; } \\
\text { mouse monoclonal, Amac }\end{array}$ & $68 \pm 3$ & $96 \pm 1$ & $86 \pm 10$ \\
\hline CD34 & $\begin{array}{l}\text { Hematopoietic precursors cells, vascular endothelial cells, fibroblasts, aortic } \\
\text { smooth muscle cells; mouse monoclonal, Amac }\end{array}$ & $70 \pm 3$ & $75 \pm 9$ & $78 \pm 10$ \\
\hline Cadherin-5 & Endothelial cells, endothelial macrophages; mouse monoclonal* & $93 \pm 7$ & $68 \pm 6$ & $79 \pm 6$ \\
\hline PN-E2 & $\begin{array}{l}\text { Endothelial cells, weak staining with fibroblasts, monocytes and macrophages; } \\
\text { mouse monoclonal, Monosan }\end{array}$ & $95 \pm 4$ & $80 \pm 9$ & $71 \pm 10$ \\
\hline EN $2 / 3$ & $\begin{array}{l}\text { Endothelial cells, some cell lines derived from melanomas, colon, } \\
\text { glioblastomas, freshly isolated monocytes and lymphocytes; mouse } \\
\text { monoclonal, BMA (Westbury, NY) }\end{array}$ & $97 \pm 1$ & $89 \pm 3$ & $74 \pm 5$ \\
\hline BW-200 & $\begin{array}{l}\text { Endothelial cells of differentiated vessels and capillaries, immature capillaries in } \\
\text { hemangiomas, mesothelium and glomerular epithelial cells; mouse } \\
\text { monoclonal, BMA }\end{array}$ & $76 \pm 16$ & $73 \pm 7$ & $58 \pm 18$ \\
\hline VCAM-1 & $\begin{array}{l}\text { Activated endothelial cells, monocytes, glomerular epithelial cells, dendritic } \\
\text { cells, myoblasts, bone marrow fibroblast; mouse monoclonal, Amac }\end{array}$ & $13 \pm 4$ & $32 \pm 4$ & $47 \pm 10$ \\
\hline ICAM-1 & $\begin{array}{l}\text { Activated endothelial cells, monocytes, granulocytes, } \mathrm{T} \text { and B cells, dendritic } \\
\text { cells, keratinocytes, chondrocytes, epithelial cells; mouse monoclonal, Amac }\end{array}$ & $11 \pm 1$ & $93 \pm 3$ & $75 \pm 3$ \\
\hline ELAM-1 & Activated endothelial cells; mouse monoclonal, Amac & NEG & $43 \pm 2$ & $46 \pm 16$ \\
\hline
\end{tabular}

Endothelial cell marker expression in untreated and cytokine-treated HUVE cells and AIDS-KS cells. HUVE cells (p6-p10) and AIDS-KS cells (p10-p13) were cultured and stained as described in Methods. Different strains of AIDS-KS cells (AIDS-KS3, -KS4, -KS6, -KS8) were tested. The results shown are the average of the percentage of positive cells from four independent experiments $+/-$ standard deviation. HUVE, untreated HUVE cells; $C T$-HUVE, cytokine-treated HUVE cells; AIDS-KS, AIDS-KS spindle cells (AIDS-KS3, -KS4, -KS6, -KS8, -KS11 cell strains). The values reported in the table represent an average of the results obtained with all AIDS-KS cell strains. * This antibody was kindly provided by Elisabetta Dejana (Istituto di Ricerche Farmacologiche "Mario Negri”, Milano, Italy)

Evaluation of the percentage of noncycling cells by FACS analysis after stimulation with Tat or $b F G F$. HUVE cells were exposed to TCM for 4-5 d and then seeded at $1.5-2 \times 10^{5}$ cells/T $75 \mathrm{~cm}^{2}$ flask in complete medium. After $16-20 \mathrm{~h}$, cells were washed with assay medium and incubated with the same medium for $24 \mathrm{~h}$. Recombinant proteins or the protein buffer only and $150 \mu \mathrm{M}$ (BrdU) were then added to the cells. After an additional incubation of $72 \mathrm{~h}$, cells were trypsinized, fixed in cold $70 \%$ ethanol and incubated for $30 \mathrm{~min}$ in $1 \mathrm{ml}$ of $2 \mathrm{~N} \mathrm{HCl}$, $0.5 \%$ Triton $\mathrm{X}-100$ at room temperature. Cells were then washed in 1 $\mathrm{ml}$ of $0.1 \mathrm{M} \mathrm{Na}_{2} \mathrm{~B}_{4} \mathrm{O}_{7}(\mathrm{pH} \mathrm{8.5)}$, resuspended in $50 \mu \mathrm{l}$ of PBS- $0.1 \%$ BSA, incubated with $10 \mu \mathrm{l}$ of FITC anti-BrdU for $30 \mathrm{~min}$ at room temperature. Cells were then washed with PBS- $0.1 \%$ BSA and resuspended in $1 \mathrm{ml}$ of propidium iodide $(5 \mu \mathrm{g} / \mathrm{ml})$. Nuclei were analyzed by flow cytometry using the Lysis software (Becton Dickinson). Noncycling cells (cells that do not replicate their DNA) are the cells which do not incorporate BrdU and, consequently, are not stained by the antiBrdU Ab.

Injection of HUVE cells in nude mice before and after exposure to cytokines from activated $T$ cells. Untreated or cytokine-treated HUVE cells $\left(3 \times 10^{6}\right)$ were injected subcutaneously into the lower back (right side) of Balb/c nu/nu athymic mice, while their negative control (media in which the cells were resuspended) were injected into the left side of the same mice, as described previously $(31,34,35)$. In all cases, cells or media (in $200 \mu \mathrm{l}$ of final volume) were mixed with an equal volume $(200 \mu \mathrm{l})$ of matrigel prior to inoculation. Mice were sacrificed 6-7 d after injection. The sites of injection were evaluated for the presence of macroscopic lesions. Tissue samples were also taken from all sites inoculated with cells or media and from sites inoculated with the negative control and fixed in formalin for histological examination. Slides were prepared from the formalin-fixed tissue blocks and analyzed microscopically after hematoxylin-eosin (H \& E) staining. The histological changes observed at the site of injection, blood vessel formation, spindle cell proliferation, acute (neutrophilic), and chronic (mononuclear) inflammatory cell infiltration and edema, were evaluated by comparison with the negative controls and histological observations were graded according to intensity from 1-5 with the minimal alteration observed given a value of 1 (intensity value).

\section{Results}

Cytokines from activated $T$ cells induce normal endothelial cells to acquire a pattern of marker expression closely resembling $K S$ spindle cells. The very early stage of $\mathrm{KS}$ is characterized by the presence of activated endothelial cells and inflammatory cell infiltration (pre-KS) followed by the appearance of the typical spindle-shaped cells $(1,6-9)$. Previous studies indicated that the spindle cells of KS have features in common with activated endothelial cells, including the expression of CD34 and of adhesion molecules such as intercellular cell adhesion molecule-1 (ICAM-1), vascular cell adhesion molecule-1 (VCAM-1) and endothelial leucocyte adhesion molecule-1 (ELAM-1) $(9,51,52)$. However, FVIII-related antigen (FVIIIRA, vWF), a typical endothelial cell marker, has not been consistently found in KS spindle cells $(8,45,48)$. To determine the origin of KS cells, cultured spindle cells were analyzed for a variety of endothelial cell specific markers and activation 


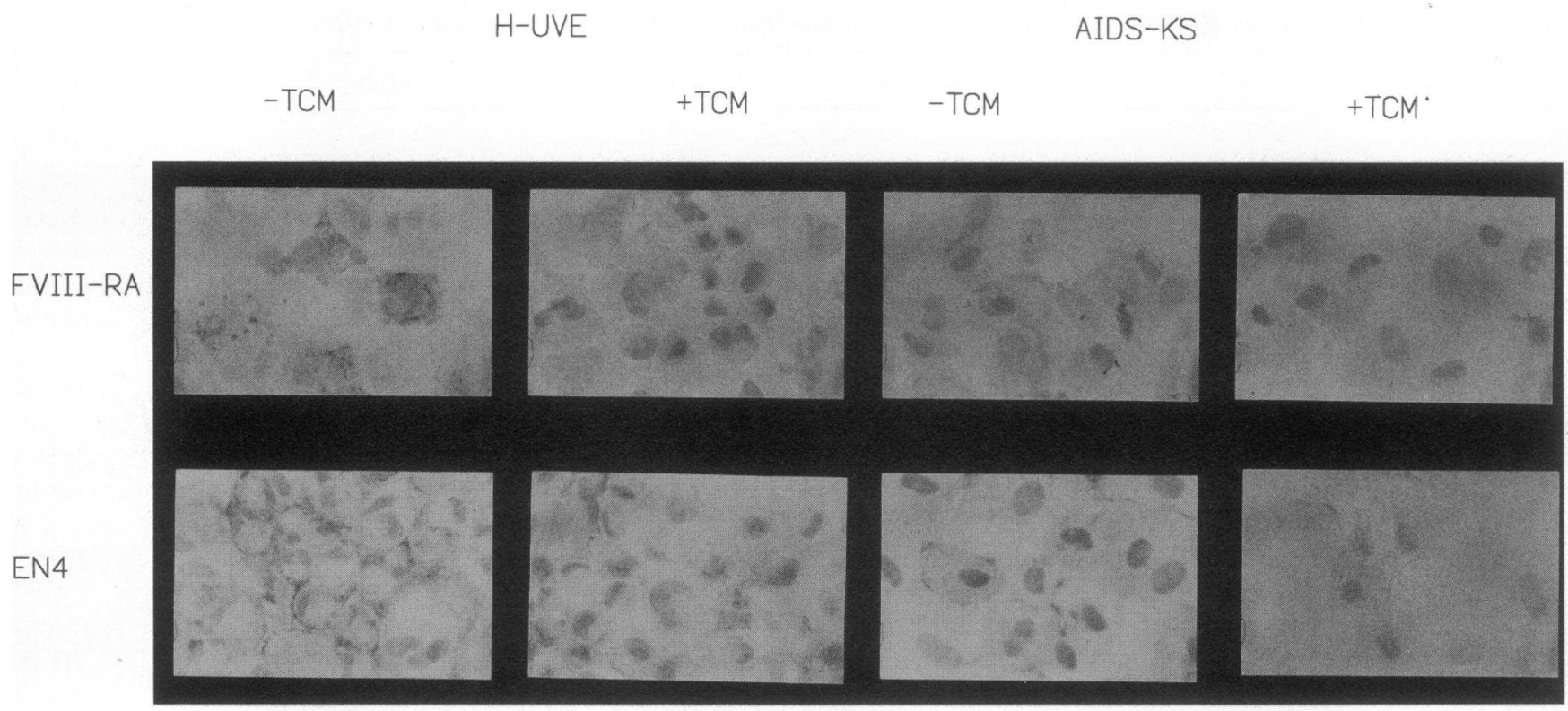

Figure 1. Expression of FVIII-RA and EN-4 in HUVE and AIDS-KS cells cultured in the absence or in the presence of TCM for $6 \mathrm{~d}$. HUVE cells (p6-p10) and AIDS-KS6 cells (p7) are shown. As described in Table I, TCM downregulate FVIII-RA and EN-4 expression in HUVE cells. AIDSKS cells, routinely cultured in the presence of TCM, do not express FVIII-RA and EN-4 (Table I). However, after $6 \mathrm{~d}$ of culture in the absence of TCM, AIDS-KS cells regain both FVIII-RA $(15 \% \pm 2)$ and EN-4 $(23 \% \pm 5)$ expression.

molecules (Table I). All cultured KS cell strains analyzed expressed CD34, cadherin-5, EN 7/44, H 4-7/33, PN-E2, EN $2 /$ 3 , and BW-200 suggesting that they are of vascular endothelial cell origin. In particular, cadherin-5 is an intercellular adhesion molecule known to be expressed only by cultured vascular endothelial cells (53). AIDS-KS cells also showed a strong positivity for activated endothelial cell markers, such as the adhesion molecules VCAM-1, ICAM-1, ELAM-1. Among them, ELAM1 is expressed only by activated endothelial cells $(54)$. However, KS cells were negative for Factor VIII-RA and EN-4/ CD31 (55). These results and previous finding $(9,47,48)$ suggested that the spindle cells of KS may represent an activated state of endothelial cells.

As inflammatory cytokines are increased in HIV-1-infected individuals $(10,12-18)$ and they mediate endothelial cell activation $(56,57)$, the same markers were analyzed in HUVE cells cultured in the absence or in the presence of TCM, which contain the same combination of inflammatory cytokines found elevated in HIV-1-infected individuals (10) (for simplicity we refer to this CM as TCM or inflammatory cytokines). As described previously (10), after treatment with TCM endothelial cells acquired a typical spindle-shaped morphology. As shown in Table I, both cytokine-activated or untreated HUVE cells expressed similar levels of CD34, cadherin-5, EN 7/44, H 4-7/33, PN-E2, EN 2/3, and BW-200. In contrast, the expression of adhesion molecules (ICAM-1, VCAM-1, and ELAM1) was increased $(56,57)$. Most importantly, FVIII-RA and EN-4 were downregulated in cytokine-treated endothelial cells (Table I and Fig. 1). As shown previously, cytokine-activated HUVE cells also expressed higher levels of the $\alpha_{5} \beta_{1}$ and $\alpha_{v} \beta_{3}$ integrin receptors and similar to those found with cultured KS cells (41). These results indicated that short-term treatment with inflammatory cytokines induces normal endothelial cells to acquire a pattern of marker expression similar to that of $\mathrm{KS}$ spindle cells.
$K S$ spindle cells cultured in the absence of TCM express FVIII-RA and EN-4/CD31. The previous results indicated that after exposure to inflammatory cytokines endothelial cells undergo changes in morphology and marker expression. In particular, FVIII-RA and EN-4/CD31 expression are downregulated in activated endothelial cells. These markers are not expressed by KS spindle cells which have been established and cultured in the presence of TCM (Table I). In addition, in vivo data of FVIII-RA staining of $\mathrm{KS}$ spindle cells have been controversial $(8,9,45,48)$, perhaps depending upon the method of detection used (58) or on the stage of the KS lesions examined (59). Recent data from our laboratory with frozen sections of AIDSassociated and classical KS lesions and a sensitive immunohistochemistry method (reference 35 and Gendelman et al., manuscript in preparation) indicate that a considerable portion of the spindle cells of KS are FVIII-RA, cadherin-5, CD34, EN-4, and ELAM-1 positive, in agreement with previous results $(9,52$, $60)$. In addition, these cells also express the $\alpha_{5} \beta_{1}$ and $\alpha_{v} \beta_{3}$ integrins (35). It has also been shown that TNF $\alpha$ and $\gamma$ IFN are capable of initiating release of vWF from endothelial cells $(61,62)$ and elevated plasma levels of vWF have been reported in HIV-1-infected individuals (63). This suggested that the exposure to inflammatory cytokines may account for the variable FVIII-RA expression in KS spindle cells both in vitro and in vivo (59).

To investigate whether the long-term culture of KS cells in the presence of TCM suppressed the expression of FVIII-RA and EN-4, different AIDS-KS cell strains (AIDS-KS4, -KS6, -KS11) at passage 9 were stained for these antigens after 6 days of culture in the absence of TCM. Although all strains were still negative for FVIII-RA, EN-4 was detected $(11-17 \%)$ in two of them (AIDS-KS6 and -KS11). To verify whether cell passage (or the time in culture with TCM) could have modulated marker expression, the same experiments were repeated with AIDS-KS6 at passage 7. In this case, KS cells expressed 


\begin{tabular}{|c|c|c|c|c|c|c|c|}
\hline \multirow[b]{2}{*}{ Cell strain } & \multirow[b]{2}{*}{ Cell passage } & \multicolumn{2}{|c|}{$\begin{array}{l}\text { Percent of EN-4+ cells by } \\
\text { immunohistochemistry }\end{array}$} & \multicolumn{2}{|c|}{$\begin{array}{l}\text { Percent of FVIII-RA+ cells } \\
\text { by immunohistochemistry }\end{array}$} & \multicolumn{2}{|c|}{$\begin{array}{l}\mathrm{vWF} \mathrm{mU} / \mathrm{ml} \text { in cell } \\
\text { supernatants }\end{array}$} \\
\hline & & $-\mathrm{TCM}$ & $+\mathrm{TCM}$ & $-\mathrm{TCM}$ & $+\mathrm{TCM}$ & -ТCM & $+\mathrm{TCM}$ \\
\hline \multirow[t]{2}{*}{ AIDS-KS4 } & $4-6$ & ND & ND & ND & ND & 0.18 & 0.42 \\
\hline & 9 & NEG & NEG & NEG & NEG & NEG & NEG \\
\hline \multirow[t]{2}{*}{ AIDS-KS6 } & 7 & $24 \pm 5$ & NEG & $15 \pm 2$ & NEG & 0.26 & 0.45 \\
\hline & .9 & $14 \pm 3$ & NEG & NEG & NEG & ND & ND \\
\hline AIDS-KS11 & 9 & $13 \pm 2$ & NEG & NEG & NEG & ND & ND \\
\hline HUVE & $6-10$ & $86 \pm 7$ & $46 \pm 1$ & $60 \pm 6$ & $10 \pm 4$ & 5.0 & ND \\
\hline
\end{tabular}

FVIII-RA and EN-4 expression by immunohistochemistry and VWF determination by ELISA in HUVE and AIDS-KS cells cultured in the absence or in the presence of TCM. HUVE and AIDS-KS cells were stained after $6 \mathrm{~d}$ of culture in the presence or in the absence of TCM, as described in Methods. Cell supernatants were collected after $3 \mathrm{~d}$ and vWF measured by ELISA. The media used to culture the cells was used as a negative control. FBS and TCM were negative for VWF. ND, not done; NEG, negative.

FVIII-RA $(15 \% \pm 2)$ and EN-4 (24\% \pm 3$)$ (Fig. 1 and Table II), while ELAM-1 expression was lower than in the presence of TCM (data not shown). Differently from HUVE cells, FVIIIRA staining in AIDS-KS cells (Fig. 1) was mostly localized on the cell membrane, suggesting that the time in culture in the absence of TCM was not sufficient to allow reorganization of FVIII-RA in a granular pattern. To confirm FVIII-RA expression by KS cells, the protein was measured in the supernatants of AIDS-KS6 p7 and AIDS-KS4 p4 cells by ELISA (Table II). vWF was detected in these cell supernatants and higher concentrations were measured after culture of the cells with TCM. Thus, the cytokines contained in TCM induce vWF release, as found previously $(61,62)$. This confirmed that AIDS$\mathrm{KS}$ cells are of endothelial origin and suggested that in HIV1 -infected individuals increased inflammatory cytokines may account for the increased plasma levels of this factor $(59,63)$.

Inflammatory cytokines decrease the endothelial cell growth response to bFGF by reducing RNA and protein synthesis in the G1 phase of the cell cycle. bFGF is an endothelial cell growth factor produced and released by cultured KS spindle cells and highly expressed in KS lesions $(33,34-36)$. Cultured $\mathrm{KS}$ cells require high levels of exogenous bFGF for growth while very low levels are needed to induce a much higher proliferative response in normal endothelial cells, such as HUVE. To verify whether inflammatory cytokines could modify the growth response of endothelial cells to bFGF, cell cycle analyses were performed with synchronized HUVE cells cultured in the absence or in the presence of TCM.

The cell transition from the quiescent to the proliferative state $(\mathrm{GO}->\mathrm{G} 1)$ requires an increase in the rate of RNA and protein synthesis ( $\mathrm{G} 1$ phase) necessary for cells to replicate their DNA (S phase) (64-70). We analyzed the effect of bFGF ( 1 and $25 \mathrm{ng} / \mathrm{ml}$ ) on RNA, protein and DNA synthesis by using synchronized HUVE cells prior to or after exposure of the cells to TCM (Fig. 2). bFGF stimulated both treated and untreated HUVE cells to synthesize RNA and proteins with a first peak within $12 \mathrm{~h}$ from its addition (Fig. 2, $A$ and $B$ ). This allowed the cells to enter the $S$ phase which begun at $24 \mathrm{~h}$ (Fig. 2 $C)$, completing the first synchronized cell cycle. At this time differences were observed in untreated versus cytokine-treated cells. While the kinetics of RNA, protein and DNA synthesis were similar in treated and untreated cells, cytokine-treatment induced a reduction of RNA, protein and DNA synthesis in response to bFGF (Fig. $2, A-C$ ). The reduction in RNA synthesis after cytokine-treatment was mostly observed between $12 \mathrm{~h}$ (92 and $72 \%$ reduction for 1 and $25 \mathrm{ng} / \mathrm{ml} \mathrm{bFGF,} \mathrm{respectively}$ [ $p<0.01]$ ) and $24 \mathrm{~h}(85$ and $79 \%$ reduction for 1 and $25 \mathrm{ng} /$ $\mathrm{ml}$ bFGF, respectively $[p<0.01])$. The reduction in protein synthesis was $86 \%$ ( $p<0.01$ ), 26 and $16 \%$ at 24,48 , and 72 $\mathrm{h}$, respectively, with $1 \mathrm{ng} / \mathrm{ml}$, while with $25 \mathrm{ng} / \mathrm{ml} \mathrm{bFGF} \mathrm{a} 53 \%$ reduction was observed at $12 \mathrm{~h}(p<0.01)$. The reduction in DNA synthesis was observed at $24 \mathrm{~h}(40 \%), 48 \mathrm{~h}(51 \%$ [ $p$ $<0.05])$ and $72 \mathrm{~h}(69 \%[p<0.01])$ with $1 \mathrm{ng} / \mathrm{ml}$ bFGF and at $48 \mathrm{~h}(8 \%)$ and $72 \mathrm{~h}(27 \%)$ with $25 \mathrm{ng} / \mathrm{ml}$ bFGF. By 48 and $72 \mathrm{~h}$, the second phase of RNA and protein synthesis were similar in untreated and cytokine-treated cells. This is likely due to the fact that the synchronization and the assays were performed in the absence of TCM, thus, the effect of cytokine treatment, as well as the synchronization itself, declined with time. These observations suggest that the effect of inflammatory cytokines is reversible within $24 \mathrm{~h}$. In addition, while with untreated HUVE cells low concentrations of bFGF $(1 \mathrm{ng} / \mathrm{ml})$ were sufficient to induce maximal DNA synthesis, higher bFGF concentrations $(25 \mathrm{ng} / \mathrm{ml})$ were required by cytokine-treated HUVE cells.

To verify whether methionine/leucine incorporation induced by bFGF corresponded to a true protein synthesis, experiments were performed in the presence or in the absence of cycloheximide $(\mathrm{CHX})$, a protein synthesis inhibitor. Time points chosen for these experiments were those presenting a significant inhibition in response to bFGF after treatment with inflammatory cytokines. With untreated HUVE cells $89 \%$ inhibition $(p<0.05)$ and $97 \%(p<0.01)$ were observed at 12 and $24 \mathrm{~h}$, respectively; with cytokine-treated HUVE cells $71 \%$ $(p<0.05)$ and $86 \%(p<0.01)$ inhibition were observed at 12 and $24 \mathrm{~h}$, respectively. This indicated that the methionine/leucine incorporation induced by bFGF is due to protein synthesis.

Thus, inflammatory cytokines reduce the metabolic activities of the G1 phase of the cell cycle in response to bFGF and, consequently, the $\mathrm{S}$ phase. To confirm this, the rate of cells in $S$ phase was analyzed by flow cytometry using exponentially growing HUVE cells cultured for $72 \mathrm{~h}$ in the presence or in the absence of TCM. As shown in Fig. 3, the percentage of cytokine-treated cells in S phase was decreased by about $30 \%$ compared to the cells grown in the absence of cytokines $(p<0.01)$. The results indicate that inflammatory cytokines reduce the en- 
A
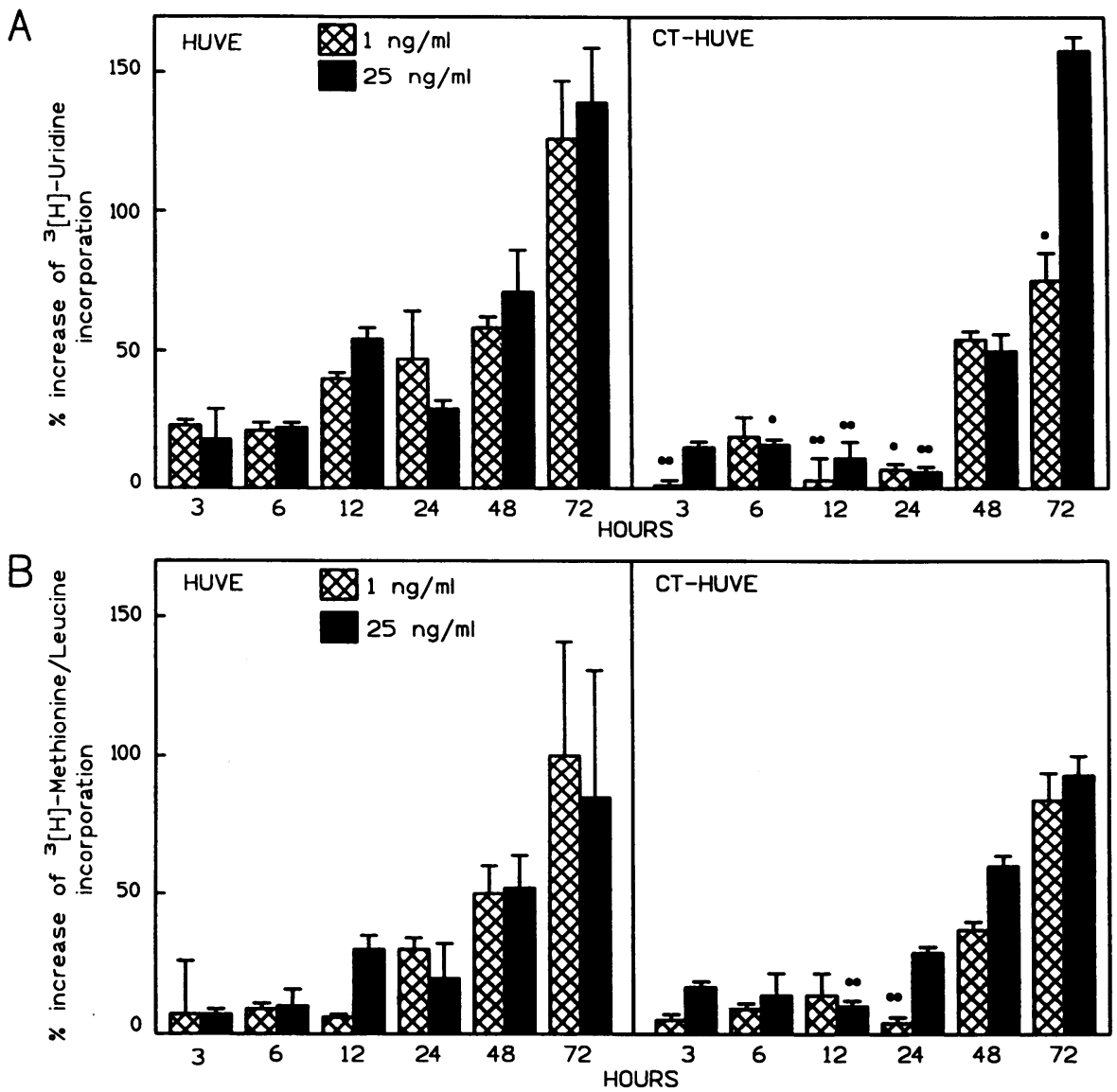

C
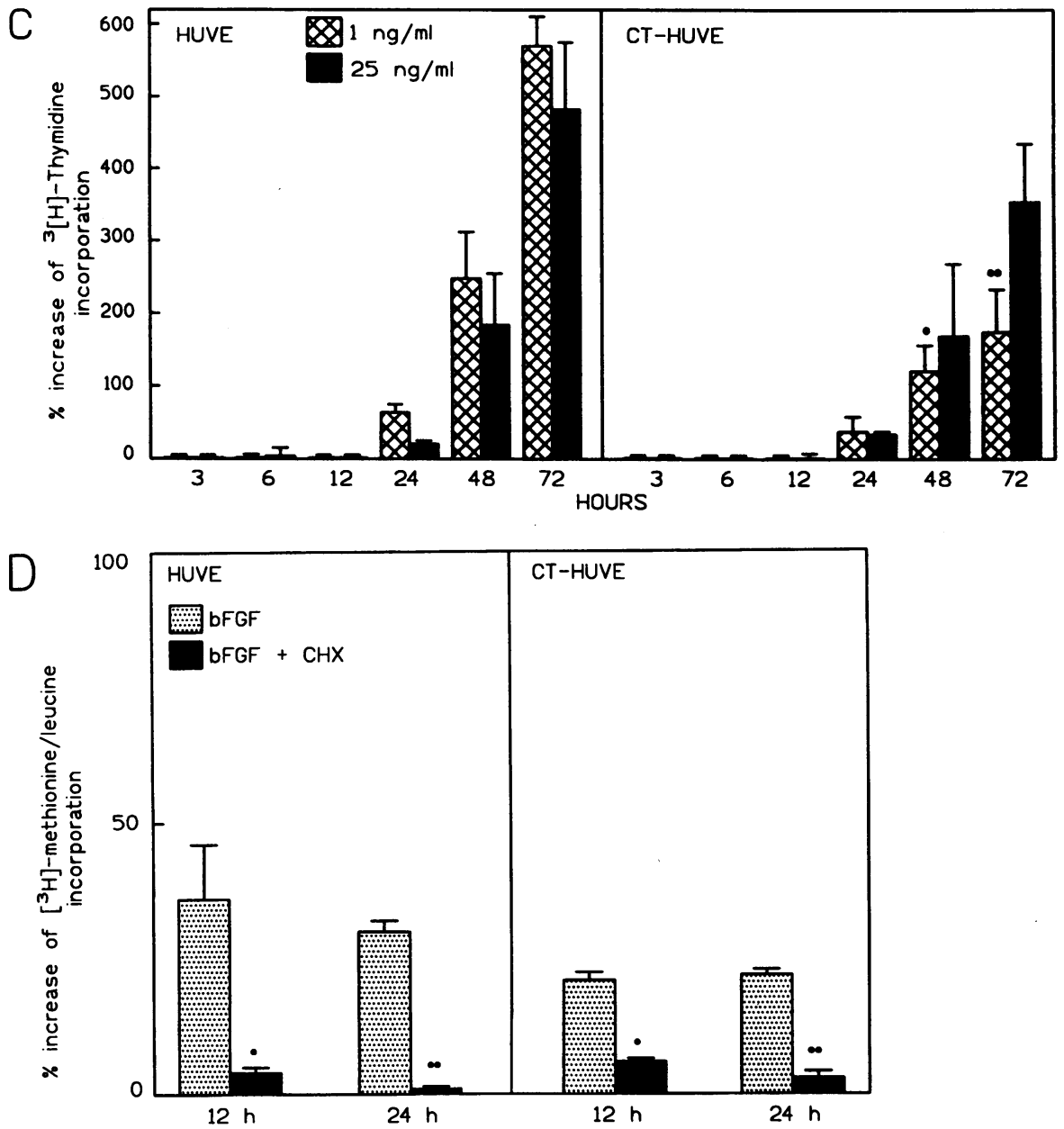

Figure 2. $(A-C)$ Increase of RNA $(A)$, protein $(B)$, and DNA $(C)$ synthesis after addition of bFGF to synchronized HUVE cells (left panels) and cytokine-treated HUVE cells (CT-HUVE, right panel). Shown is the percent increase of $\left[{ }^{3} \mathrm{H}\right]$ uridine $(A),\left[{ }^{3} \mathrm{H}\right]-$ methionine/leucine $(B)$ and $\left[{ }^{3} \mathrm{H}\right]$ thymidine $(C)$ incorporation at different time points $(3$, $6,12,24,48$, and $72 \mathrm{~h}$ ) after the addition of $1 \mathrm{ng} / \mathrm{ml}$ (cross-hatched bars) or $25 \mathrm{ng} / \mathrm{ml}$ (solid bars) of bFGF over the incorporation obtained with the protein buffer (negative control). The cpm values obtained with the protein buffer during the time course experiments for HUVE cells were 115-1028 for RNA synthesis, 111-988 for protein synthesis at 3 and $72 \mathrm{~h}$, respectively, and $72-319$ for DNA synthesis at 24 and $72 \mathrm{~h}$, respectively. For CT-HUVE cells, 253-859 for RNA synthesis, 80-1195 for protein synthesis, at 3 and $72 \mathrm{~h}$, respectively and $61-360$ for DNA synthesis at 24 and $72 \mathrm{~h}$, respectively. These values were assumed as $0 \%$ increase. The differences between untreated and cytokine-treated cells are statistically significant ([.] $p<0.05 ;[.] p<0.01$.$) . (D) In-$ hibition of bFGF-induced $\left[{ }^{3} \mathrm{H}\right]$ methionine/ leucine incorporation by cycloheximide (CHX). Shown is the percent increase of $\left[{ }^{3} \mathrm{H}\right]$ methionine/leucine incorporation at 12 and $24 \mathrm{~h}$, after the addition of $25 \mathrm{ng} / \mathrm{ml}$ bFGF in the presence (solid bars) or in the absence (shaded bars) of CHX $(10 \mu \mathrm{g} / \mathrm{ml})$ over the incorporation obtained with the protein buffer (negative control). (.) $p<0.05$; (..) $p<0.01$. 


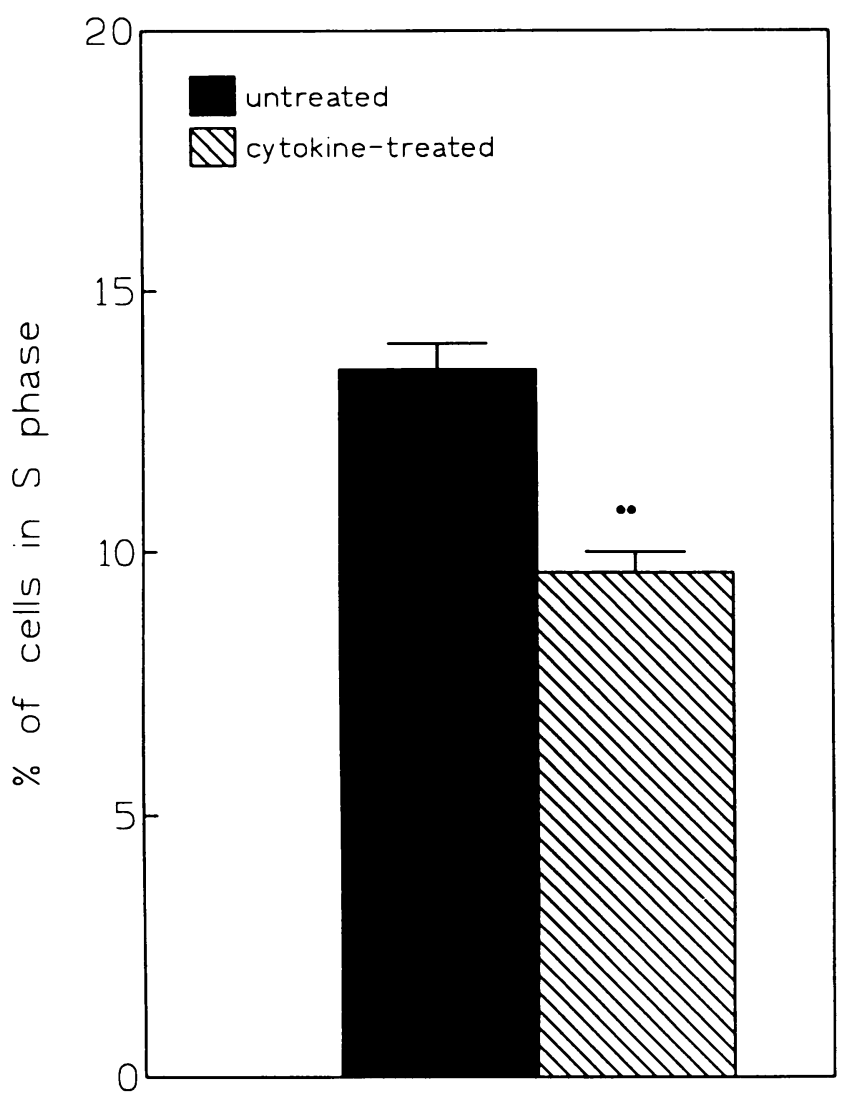

Figure 3. Inflammatory cytokines decrease the rate of HUVE cells in $\mathrm{S}$ phase in response to bFGF. Shown is the percent of cells in $\mathrm{S}$ phase cultured in the growth medium containing bFGF $(5 \mathrm{ng} / \mathrm{ml})$ and in the presence ( hatched bar) or in the absence ( solid bar) of inflammatory cytokines. The distribution of the cell populations in the different phases of the cell cycle was analyzed by FACS analysis as described in Methods. The differences in the percent of cells in $S$ phase between untreated and cytokine-treated cells are statistically significant $([.] p<0.01$.$) .$

dothelial cell growth response to bFGF and increase the concentration of the cytokine required to induce maximal cell growth.

In the presence of inflammatory cytokines Tat induces the GI-S transition of the endothelial cell cycle. We have previously shown that, under standard conditions. HUVE cells do not proliferate in response to Tat and that they require a previous exposure to inflammatory cytokines to become responsive to the mitogenic effect of the protein $(10,39)$. These cytokines increase the expression and the affinity of the integrins $\alpha_{5} \beta_{1}$ and $\alpha_{v} \beta_{3}$, which function as the receptors for Tat (41). To analyze the effect of inflammatory cytokines on the cell growth responsiveness to Tat, cell cycle analysis was performed after addition of Tat ( 1 and $25 \mathrm{ng} / \mathrm{ml}$ ) to untreated versus cytokineactivated and synchronized HUVE cells. In the absence of inflammatory cytokines, very low levels of RNA and protein synthesis and no DNA synthesis were observed after the addition of 1 or $25 \mathrm{ng} / \mathrm{ml}$ of exogenous Tat to the cells, suggesting that Tat may not be able to bind or to signal to untreated cells (Fig. 4, $A-C$, left panels) (41). However, with cytokine-treated cells. Tat induced all the metabolic events required for cell growth. Within 3-6 h Tat stimulated RNA synthesis (Fig. 4 A, right panel $[p<0.01$ or $p<0.05])$ and a lower increase of protein synthesis (Fig. 4 B, right panel). while DNA synthesis was stimulated by Tat within $24 \mathrm{~h}$ from its addition to the cells ( Fig. $4 C$, right panel $[p<0.01])$. As described previously (40). Tat induced DNA synthesis in a dose-dependent fashion (Fig. 4 C, right panel), while RNA synthesis appeared not to be dose-dependent at the concentrations tested. This is may be due to the fact that thymidine and uridine incorporation result from different processes, differently regulated during the cell cycle.

To evaluate whether the methionine/leucine incorporation induced by Tat was due to protein synthesis, experiments were performed in the presence or in the absence of CHX. As shown in Fig. $4 \mathrm{D}, \mathrm{CHX}$ inhibited Tat-induced methionine/leucine incorporation by $50 \%(12 \mathrm{~h})$ and $86 \%(24 \mathrm{~h})$ in cytokinetreated HUVE cells $(p<0.01)$, indicating that the low levels of methionine/leucine incorporation induced by Tat result from protein synthesis.

The results indicated that Tat stimulates quiescent and cytokine-treated endothelial cells to replicate their DNA by acting on the Gl phase of the cell cycle. These results were confirmed by evaluating the effects of Tat on the distribution of cytokinetreated HUVE cells within the different phases of the cell cycle (Fig. 5). After addition of Tat the percentage of noncycling cells (the cells that did not go through the $S$ phase in all the duration of the assay) was reduced by $20-30 \%(p<0.01$ and $p<0.05$ ) while that with bFGF, used as control, was reduced by $36 \%(p<0.01)$.

Cytokine-treated endothelial cells induce KS-like lesions after inoculation in nude mice. We have previously shown that injection of AIDS-KS cells into nude mice induces vascular lesions of mouse cell origin closely resembling early human KS $(31,34,35)$. These lesions which develop in response to the production of cytokines, particularly bFGF, by inoculated KS spindle cells (33-35) disappear when the proliferation of the spindle cells terminates, are not elicited by fixed cells or by normal control cells such as $\operatorname{HUVE}(31,35)$. To determine whether inflammatory cytokines induce normal endothelial cells to acquire the ability to induce KS-like lesions in nude mice. untreated or cytokine-treated cells, or the media in which they were resuspended, were injected into nude mice (Table III). Cytokine-treated HUVE cells induced macroscopic vascular lesions in $50 \%$ of the inoculated mice while no lesions were observed after inoculation of untreated HUVE or media alone (Table III ). Furthermore, cytokine-treated cells induced histological alterations characteristic of early stage KS, and indistinguishable from those induced by cultured KS cells, in 100\% of the mice inoculated (Table II and Fig. 6). These include angiogenesis, spindle cell growth, edema, and inflammatory cell infiltration. These results indicate that inflammatory cytokines induce normal endothelial cells to acquire angiogenic capabilities and KS-like lesion promoting activity.

\section{Discussion}

Previous studies have suggested that, at least in early stage. $\mathrm{KS}$ is a hyperplastic/proliferative disease of vascular origin mediated by cytokines $(10,11,71)$. In particular, immune activation and consequent production of inflammatory cytokines (10. 12-18) may cooperate with bFGF and the HIV-1 Tat protein in the induction and progression of $\mathrm{KS}$ in homosexual/ bisexual men (10.35). However, the origin of the spindle cells of KS and the mechanism( $s$ ) by which inflammatory cytokines may cooperate in $\mathrm{KS}$ pathogenesis it is not yet clear. Here we present evidence that KS spindle cells are of endothelial origin 

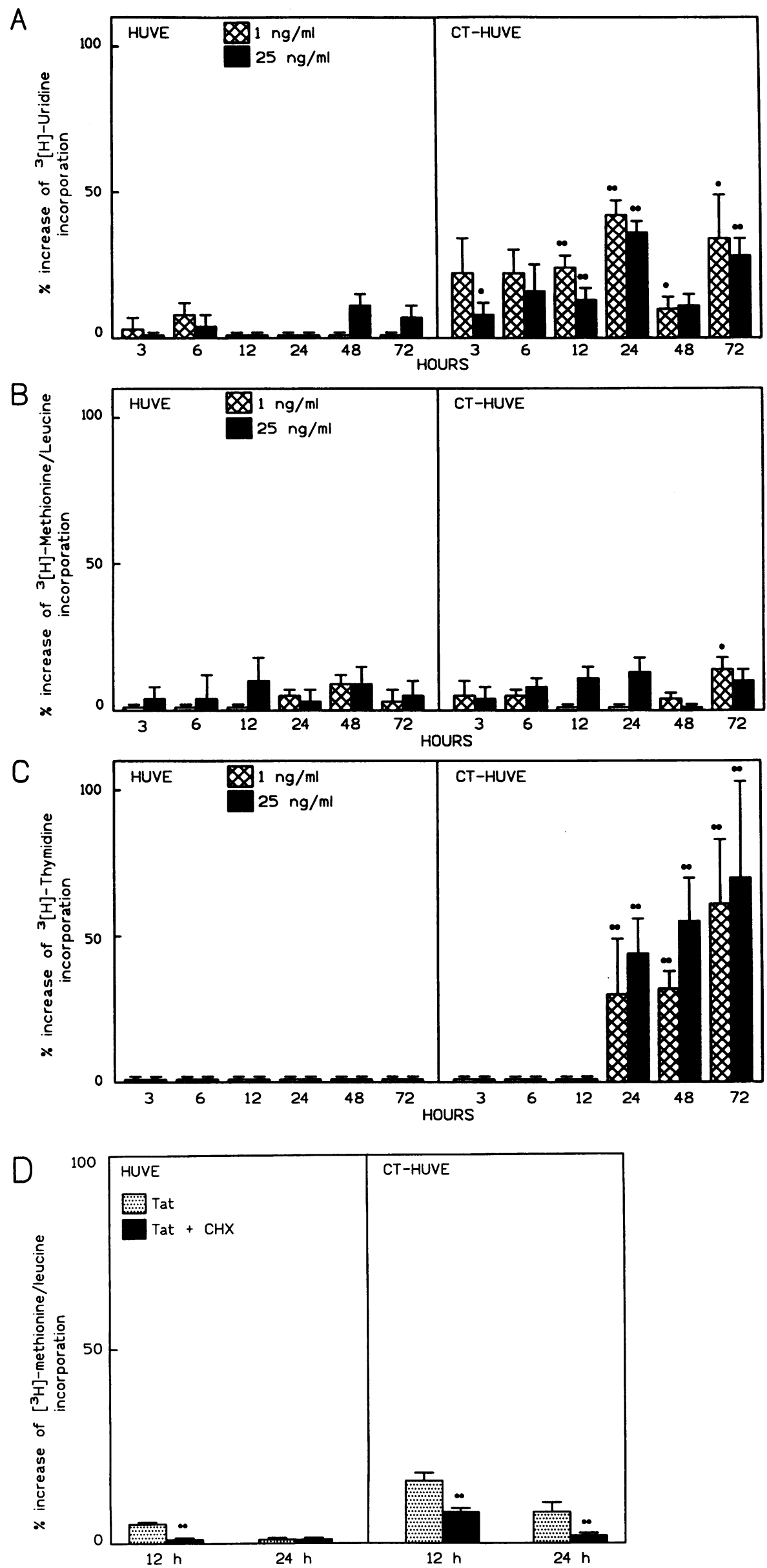

Figure 4. $(A-C)$ Increase of RNA $(A)$, protein $(B)$, and DNA $(C)$ synthesis after addition of Tat to synchronized HUVE cells (left panel) and cytokine-treated HUVE cells (CT-HUVE, right panel). Shown is the percent increase of $\left[{ }^{3} \mathrm{H}\right]$ uridine $(A),\left[{ }^{3} \mathrm{H}\right]-$ methionine/leucine $(B)$ and $\left[{ }^{3} \mathrm{H}\right]$ thymidine $(C)$ incorporation at different time points (3, $6,12,24,48$, and $72 \mathrm{~h}$ ) after the addition of $1 \mathrm{ng} / \mathrm{ml}$ (cross-hatched bars) or $25 \mathrm{ng} / \mathrm{ml}$ (solid bars) of Tat to the cells over the incorporation obtained with the protein buffer (negative control). The cpm values obtained with the protein buffer during the time course experiments for RNA, protein and DNA synthesis have been reported in the Legend to Fig. 1. These values were assumed as $0 \%$ increase. The differences between untreated and cytokine-treated cells are statistically significant ([.]p<0.05; [..]p<0.01). (D) Inhibition of Tat-induced $\left[{ }^{3} \mathrm{H}\right]$ methionine/ leucine incorporation by CHX. Shown is the percent increase of $\left[{ }^{3} \mathrm{H}\right]$ methionine/leucine incorporation at 12 and $24 \mathrm{~h}$, after the addition of $25 \mathrm{ng} / \mathrm{ml}$ of Tat in the presence (solid bars) or in the absence (shaded bars) of CHX $(10 \mu \mathrm{g} / \mathrm{ml})$ over the incorporation obtained with the protein buffer (negative control). (..) $p<0.01$. 


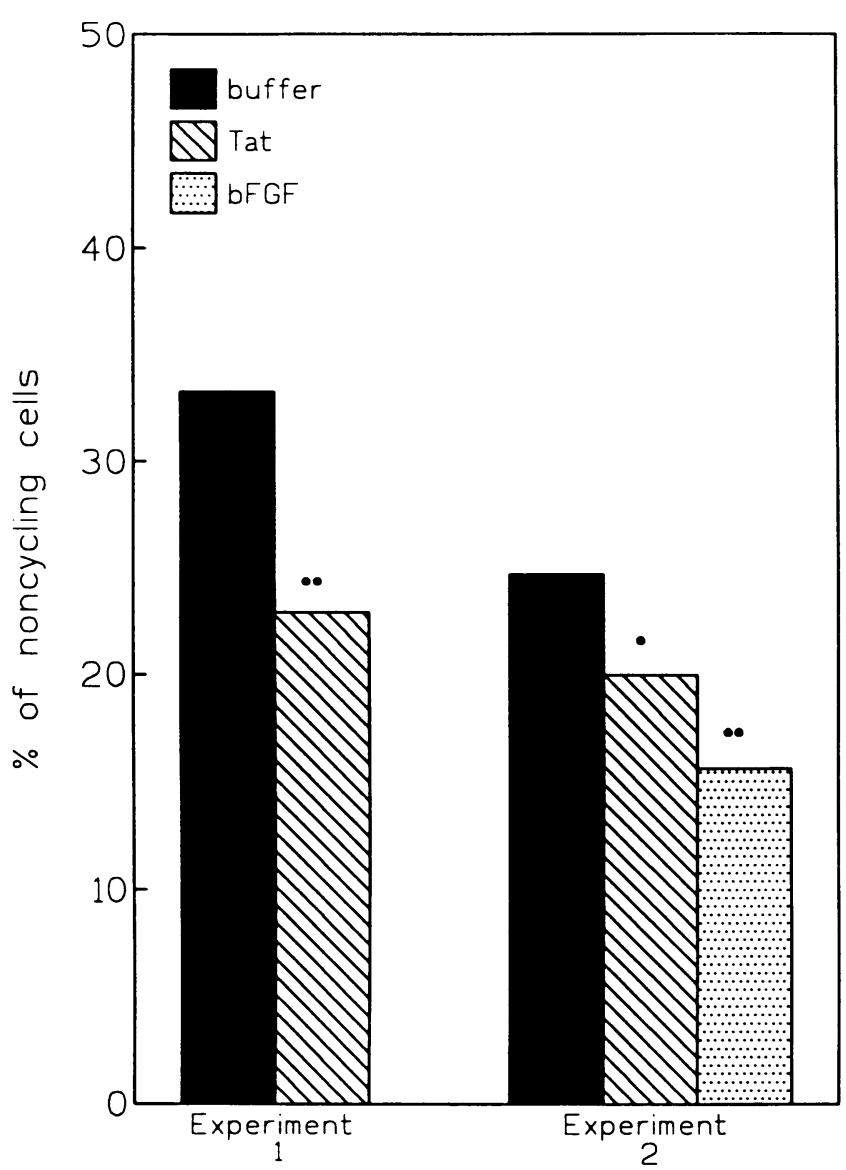

Figure 5. Recombinant Tat protein or bFGF decrease the rate of noncycling cytokine-treated HUVE cells. Shown is the percent of noncycling cells after addition of Tat ( hatched bars, $10 \mathrm{ng} / \mathrm{ml}$ ), bFGF ( shaded bars, $10 \mathrm{ng} / \mathrm{ml}$ )) or control buffer (solid bars) to synchronized cytokine-treated HUVE cells from two different experiments. The assay was performed as described in Methods. Because of the interexperimental variation, due to the fact that the proliferative rate of HUVE cells varies with cell passage, results from different experiments are shown separately. In this case statistical analysis ([.] $p<0.05:[.] p<0.01$. refers to results within each experiment.

and have an activated phenotype. In addition, the same inflammatory cytokines increased in HIV-1-infected individuals induce normal endothelial cells to acquire the phenotypic and functional features of KS spindle cells.
Cultured KS cells express endothelial specific cell markers (cadherin-5, CD34, EN 7/44, H 4-7/33, PN-E2, EN 2/3, and BW-200), and adhesion molecules (ICAM-1, VCAM-1, and ELAM-1) but not FVIII-RA or EN-4 (Table I). However, after culture in the absence of inflammatory cytokines, FVIII-RA and EN-4 expression reappear in low passage KS cells (Fig. 1 and Table II). Conversely, inflammatory cytokines induce normal endothelial cells to acquire a phenotype similar or identical to KS spindle cells including a reduction of FVIII-RA and EN-4 expression and the increase of adhesion molecules (ICAM-1, VCAM-1, and ELAM-1) to levels similar to KS cells (Table I). This indicates that cultured KS cells are of endothelial origin and that inflammatory cytokines regulate the expression of endothelial specific cell markers. This may also account for the variable FVIII-RA expression found in KS spindle cells in vivo $(8,9,35,45,48,60)$ and for the increased circulating levels of vWF found in HIV-1-infected individuals (63).

Although bFGF acts as a growth factor for both AIDS-KS and endothelial cells (33), a different proliferative response has been observed with these two cell types $(10,11)$. Our results indicate that cytokine-treatment induces endothelial cells to acquire a growth response to bFGF similar to that observed with AIDS-KS cells (Figs. 2 and 3 ). In particular, inflammatory cytokines reduce the metabolic events induced by bFGF in the G1 phase of the cell cycle (Fig. 2, $A-C$ ) and the number of HUVE cells in S phase (Fig. 3 ). In addition, they increase the concentrations of bFGF required for maximal cell growth. This may be due to a reduction in the expression of the FGF receptors by cytokines, as suggested in previous studies with IL-1 and $\gamma$ IFN $(72,73)$, both contained in TCM, and/or to the activation of bFGF expression by these cytokines $(37,38,38 \mathrm{a})$.

We have previously demonstrated that Tat is a growth factor for AIDS-KS cells ( 39 ). However, very low metabolic activities and no cell growth are induced by Tat on endothelial cells (Fig. 4, A-C, left panels). To the contrary, after exposure to inflammatory cytokines, Tat stimulates in normal endothelial cells the metabolic events required for cell growth (Figs. 4 and 5 ). Although the effect of Tat on protein synthesis is weak, Tat rapidly induced RNA synthesis, followed by DNA synthesis. The low increase in protein synthesis induced by Tat may be due to the fact that Tat induces the synthesis of specific cell cycle regulatory proteins which are undetectable by our assay, as was proposed for other systems $(68,70,74)$.

Inoculation of AIDS-KS spindle cells in nude mice induces the development of vascular lesions of mouse cell origin ( 31 . 34,35 ) which are characterized by angiogenesis, spindle cell

Table III. Cytokine-treated HUVE (CT-HUVE) Cells Inoculated in Nude Mice Induce Vascular Lesions Closely Resembling Early KS

\begin{tabular}{lcccrrr}
\hline & Lesion* & Angiogenesis & Spindle cells & Acute inflammation & Chronic inflammation \\
\hline Medium & $0 \%(5)$ & $0 \%(0)$ & $0 \%(0)$ & $0 \%(0)$ & $0 \%(0)$ \\
HUVE & $0 \%(12)$ & $0 \%(0)$ & $0 \%(0)$ & $0 \%(0)$ & $0 \%(0)$ & $0 \%(0)$ \\
CT-HUVE & $50 \%(12)$ & $100 \%(4)$ & $100 \%(5)$ & $100 \%(4)$ & $10 \%(3)$
\end{tabular}

Induction of KS-like lesions after inoculation of cytokine-treated HUVE cells in nude mice. Reported is the percentage of mice developing macroscopic vascular lesions and the percentage of mice developing histological alterations. The number of mice inoculated and the intensity value for each histopathologic feature are indicated in parenthesis. Cytokine-treated (CT-HUVE) and untreated HUVE cells were cultured for 5 days in the presence of TCM. Medium, HUVE or CT-HUVE were mixed 1:1 with matrigel and inoculated subcutaneously into nude mice $\left(3 \times 10^{6}\right.$ cells/ site). Mice were sacrificed 6 days after inoculation and tissue slides examined after $\mathrm{H} \& \mathrm{E}$ staining. * Percentage of mice developing macroscopic vascular lesions (size ranging from $4 \times 5$ to $7 \times 7 \mathrm{~mm}$ ). Parenthesis show the number of mice inoculated. Percentage of mice developing histological alterations. Parenthesis show the average "intensity" value for each histopathological feature observed per each experimental condition. 


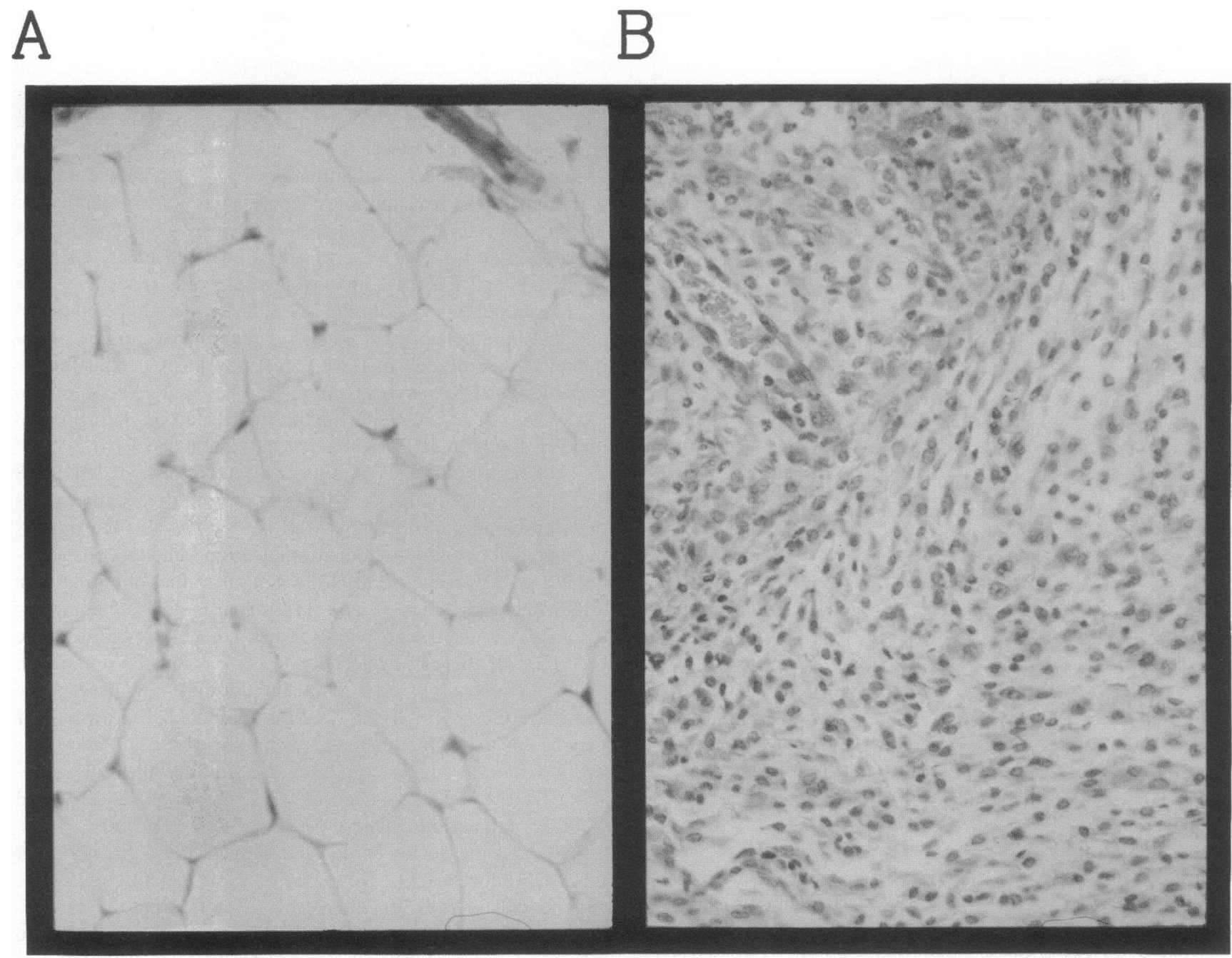

Figure 6. Cytokine-activated HUVE cells induce KS-like lesions in nude mice. Shown are the examples of the histopathology (H \& E staining, $40 \times$ magnification) of the site of injection from mice inoculated with untreated HUVE cells $(A)$ or cytokine-treated HUVE cells $(B)$.

growth, inflammatory infiltration and edema, and closely resemble early KS. Our results demonstrate that cytokine-treated endothelial cells induce angiogenesis and KS-like lesions in nude mice. This is likely to be due to the activation of the production of the same cytokines expressed by AIDS-KS spindle cells (bFGF, IL-1, IL-6, GM-CSF) as indicated by previous studies (33-35, 37, 71, 75-79).

These results indicate that inflammatory cytokines perturb the phenotype and growth behavior of normal endothelial cells inducing phenotypic and functional changes similar to AIDS$\mathrm{KS}$ cells. These changes are simultaneous after addition of cytokines. As immune activation is frequent in homosexual/bisexual men, inflammatory cell infiltration is present in early $\mathrm{KS}$, and inflammatory cytokines are expressed in AIDS-KS tissues, these data suggest that chronic immune activation and release of inflammatory cytokines may act as a predisposing factor and cooperate with bFGF and extracellular Tat in the induction and progression of $\mathrm{KS}$.

\section{Acknowledgments}

We thank M. Raffeld (LP, NIH) for the histological examination and help in the staining experiments; P. Wingfield (National Institute of
Diabetes and Digestive Kidney Diseases, National Institutes of Health, Bethesda, MD) and J. Brady (Laboratory of Molecular Virology, National Cancer Institute [NCI]) for the Tat protein preparations; E. Dejana (Istituto di Ricerche Farmacologiche "Mario Negri", Milano, Italy) for the monoclonal antibody against cadherin-5; V. Kao (Laboratory of Tumor Cell Biology [LTCB], NCI) for technical help; F. Ensoli (Pediatric Branch, NCI); A. Cafaro (Retrovirology, Henry M. Jackson Foundation, Rockville, MD); G. Barillari (LTCB, NCI) for helpful discussions; and particularly, Dr. R. C. Gallo (LTCB, NCI) for critical review of the manuscript and support of this work.

\section{References}

1. Friedman-Kien, A. E. 1981. Disseminated Kaposi's sarcoma syndrome in young homosexual men. J. Am. Acad. Dermatol. 5:468-471.

2. Hymes, K. B., I. Cheung, J. B. Greene, N. S. Proste, A. Marcus, H. Ballard, D. C. William, and L. S. Laubenstein. 1981. Kaposi's sarcoma in homosexual men - a report of eight cases. Lancet. ii:596-600.

3. Maurice, P. D. L., N. P. Smith, and A. J. Pinching. 1982. Kaposi's sarcoma with benign course in a homosexual. Lancet. i:571.

4. Jaffe, H. W., K. Choi, P. A. Thomas, H. W. Haverkos, D. M. Auebach, M. E. Guinan, M. F. Rogers, T. J. Spira, W. W. Darrow, M. A. Kramer, S. M. Friedman, J. M. Monroe, A. E. Friedman-Kien, L. S. Laubenstein, M. Marmor B. Safai, S. K. Dritz, S. J. Crispi, S. L. Fannin, S. P. Orkwois, A. Kelter, W. R. Rushing, S. B. Thacker, and J. W. Curran. 1983. National case-control study of 
Kaposi's sarcoma and Pneumocystis carinii pneumonia in homosexual men: part I. epidemiologic results. Ann. Intern. Med. 99:145-151.

5. Haverkos, H. W., D. P. Drotman, and M. Morgan. 1985. Prevalence of Kaposi's sarcoma among patients with AIDS. N. Engl. J. Med. 312:1518.

6. Gottlieb, G. J., and A. B. Ackerman. 1982. Kaposi's sarcoma: an extensively disseminated form in young homosexual men. Hum. Pathol. 13:882-892.

7. MacNutt, N. S., V. Fletcher, and M. A. Conant. 1983. Early lesions of Kaposi's sarcoma in homosexual men. An ultrastructural comparison with other vascular proliferations in skin. Am. J. Pathol. 111:62-77.

8. Ruszczak, Z., A. Mayer-Da Silva, and C. E. Orfanos. 1987. Kaposi's sarcoma in AIDS. Multicentric angioneoplasia in early skin lesions. Am. J. Dermatol. Pathol. 9:388-398.

9. Regezi, S. A., L. A. MacPhail, T. E. Daniels, Y. G. De Souza, J. S. Greenspan, and D. Greenspan. 1993. Human immunodeficiency virus-associated oral Kaposi's sarcoma: heterogeneous cell population dominated by spindleshaped endothelial cells. Am. J. Pathol. 143:240-249.

10. Barillari, G., L. Bounaguro, V. Fiorelli, J. Hoffman, F. Michaels, R. C. Gallo, and B. Ensoli. 1992. Effects of cytokines from activated immune cells on vascular cell growth and HIV-1 gene expression. J. Immunol. 149:3727-3734.

11. Ensoli, B., G. Barillari, and R. C. Gallo. 1992. Pathogenesis of AIDSassociated Kaposi's sarcoma. Immunol. Rev. 127:147-155.

12. Lepe Zanuga, J. L., P. W. A. Mansell, and E. M. Hersh. 1987. Idiopathic production of interleukin-1 in acquired immune deficiency syndrome. J. Clin. Microbiol. 25:1695-1700.

13. Lahdevirta, J., C. P. J. Maury, A. M. Teppo, and H. Repo. 1988. Elevated levels of circulating cachectin/tumor necrosis factor in patients with acquired immunodeficiency syndrome. Am. J. Med. 85:289-291.

14. Hober, D., A. Haque, P. Wattre, G. Beaucaire, Y. Mouton, and A. Capron. 1989. Production of tumor necrosis factor $\alpha$ (TNF $\alpha$ ) and interleukin-1 (IL-1) in patients with AIDS. Enhanced level of TNF $\alpha$ is related to a higher cytotoxic activity. Clin. Exp. Immunol. 78:329-333.

15. Emilie, D., M. Peuchmaur, M. C. Maillot, M. C. Crevon, N. Brousse, J. F. Delfraissy, J. Dormont, and P. Galanaud. 1990. Production of interleukins in human immunodeficiency virus-1-replicating lymph nodes. J. Clin. Invest. 86:148-159.

16. Honda, M., K. Kitamura, Y. Mizutani, M. Oishi, M. Arai, T. Okura, S. Igarahi, K. Yasukawa, T. Hirano, Y. Kishimoto, R. Mitsuyasu, J. C. Chermann, and T. Tokugana. 1990. Quantitative analysis of serum IL-6 and its correlation with increased levels of serum IL-2R in HIV-1-induced diseases. J. Immunol. 145:4059-4064.

17. Vyakarnam, A., P. Matear, A. Meager, G. Kelly, B. Stanley, I. Weller, and P. Beverley. 1991. Alterated production of tumor necrosis factors alpha and beta and interferon gamma by HIV-1 infected individuals. Clin. Exp. Immunol. 84:109-115.

18. Fan, J., H. Z. Bass, and J. L. Fahey. 1993. Elevated IFN-gamma and decreased IL-2 gene expression are associated with HIV-1 infection. J. Immunol. 152:5031-5037.

19. Shrearer, G. M., and R. B. Levy. 1983. Noninfectious cofactors in susceptibility to AIDS: possible contributions of semen, HLA alloantigens, and lack of natural resistance. Ann. NY Acad. Sci. 437:49-57.

20. Hersh, E. M., J. M. Reuben, A. Rios, P. W. Mansell, G. R. Newell, J. E. McClure, and A. L. Goldstein. 1983. Elevated serum thymosin alpha 2 levels associated with evidence of infectious diseases or Kaposi's sarcoma. N. Engl. J. Med. 308:45-46.

21. Levy, J. A., and J. L. Ziegler. 1983. Acquired immunodeficiency syndrome is an opportunistic infection and Kaposi's sarcoma results from secondary immune stimulation. Lancet. 2:78-81.

22. Kramer, A., S. Z. Wiktor, D. Fuchs, S. Milstien, M. H. Gail, F. J. Yellin, R. J. Biggar, H. Wachter, S. Kaufmann, W. A. Blattner, and J. J. Goedert. 1989. Neopterin: a predictive marker of acquired immune deficiency sindrome in human immunodeficiency virus infection. J. Acquir. Immune Defic. Syndr. 2:291-296.

23. Oxholm, A., P. Oxholm, H. Permin, and L. Bendtzen. 1989. Epidermal tumor necrosis factor alfa and interleukin 6-like activities in AIDS-related Kaposi's sarcoma. APMIS. 97:533-538.

24. Cai, J., P. S. Gill, R. Masood, P. Chandrasoma, B. Jung, R. E. Law, and S. F. Radka. 1994. Oncostatin-M is an autocrin growth factor in Kaposi's sarcoma. Am. J. Pathol. 145:74-79.

25. Rubinstein, P., W. M. Rothman, and A. Friedman-Kien. 1984. Immunologic and immunogenetic findings in patients with epidemic Kaposi's sarcoma. Antibiot. Chemother. 32:87-98.

26. Ballard, H. S. 1985. Disseminated Kaposi's sarcoma without lymphocyte abnormalities. Arch. Inter. Med. 145:547.

27. Lane, H. C., H. Masur, E. P. Gelmann, D. L. Longo, R. G. Steis, T. Chused, G. Wahlen, L. C. Edgar, and A. S. Fauci. 1985. Correlation between immunologic function and clinical subpopulations of patients with the acquired immune deficiency syndrome. Am. J. Med. 78:417-422.

28. Kriegel, R. L., C. M. Odajnyk, L. J. Laubenstaein, R. Ostreicher, J. Wernz, J. Vilcek, P. Rubinstein, and A. E. Friedman-Kien. 1985. Therapeutic trial of interferon-gamma in patients with epidemic Kaposi's sarcoma. J. Biol. Response Mod. 4:358-364.
29. Kriegel, R. L., K. A. Padavic-Shaller, A. R. Rudolph, B. J. Poiesz, and R. L. Comis. 1989. Exacerbation of epidemic Kaposi's sarcoma with a combination of interleukin-2 and gamma-interferon: results of a phase 2 study. J. Biol. Response Mod. 8:359-365.

30. Nakamura, S., S. Z. Salahuddin, P. Biberfeld, B. Ensoli, P. D. Markham, F. Wong-Staal, and R. C. Gallo. 1988. Kaposi's sarcoma cells: long term culture with growth factor from retrovirus-infected CD4+ T cells. Science (Wash. DC). 242:427-430.

31. Salahuddin S. Z., S. Nakamura, P. Biberfeld, M. H. Kaplan, P. D. Markham, L. Larsson, and R. C. Gallo. 1988. Angiogenic properties of Kaposi's sarcoma-derived cells after long-term culture in vitro. Science (Wash. DC). 242:430-433.

32. Folkman, J., and M. Klagsbrun. 1987. Angiogenic factors. Science (Wash DC). 235:442-477.

33. Ensoli, B., S. Nakamura, S. Z. Salahuddin, P. Biberfeld, L. Larsson, B Beaver, F. Wong-Staal, and R. C. Gallo. 1989. AIDS-Kaposi's sarcoma-derived cells express cytokines with autocrine and paracrine growth effects. Science (Wash. DC). 243:223-226.

34. Ensoli, B., P. Markham, V. Kao, G. Barillari, V. Fiorelli, R. Gendelman, M. Raffeld, G. Zon, and R. C. Gallo. 1994. Block of AIDS-Kaposi's sarcoma (KS) cell growth, angiogenesis, and lesion formation in nude mice by antisense oligonucleotide targeting basic fibroblast growth factor. J. Clin. Invest. 94:17361746.

35. Ensoli, B., R. Gendelman, P. Markham, V. Fiorelli, S. Colombini, M Raffeld, A. Cafaro, H. Chang, J. N. Brady, and R. C. Gallo. 1994. Synergy between basic fibroblast growth factor and human immunodeficiency virus type 1 Tat protein in induction of Kaposi's sarcoma. Nature (Lond.). 321:674-680.

36. Xerri, L., J. Hassoun, J. Planches, V. Guigov, J. J. Grob, P. Parc, D. Birnbaum, and O. deLapeyriere. 1991. Fibroblast growth factor gene expression in AIDS-Kaposi's sarcoma detected by in situ hybridization. Am. J. Pathol. 138:915.

37. Gay, C. G., and J. A. Winkles. 1991. Interleukin 1 regulates heparinbinding growth factor 2 gene expression in vascular smooth muscle cells. Proc. Natl. Acad. Sci. USA. 88:296-300.

38. Okamura, K., Y. Sato, T. Matsuda, R. Hananaka, M. Ono, K. Kohno, and M. Kuwano. 1992. Endogenous basic fibroblast growth factor-dependent induction of collagenase and interleukin-6 in tumor necrosis factor-treated human microvascular endothelial cells. J. Biol. Chem. 266:19162-19165.

38a. Samaniego, F., P. D. Markham, R. C. Gallo, and B. Ensoli. 1995. Inflammatory cytokines induce AIDS-Kaposi's sarcoma (KS)-derived spindle cells to produce and release basic fibroblast growth factor and enhance KS-like lesion formation in nude mice. J. Immunol. In press.

39. Ensoli, B., G. Barillari, S. Z. Salahuddin, R. C. Gallo, and F. Wong-Staal. 1990. Tat protein of HIV-1 stimulates growth of cells derived from Kaposi's sarcoma lesions of AIDS patients. Nature (Lond.). 344:84-86.

40. Ensoli, B., L. Buonaguro, G. Barillari, V. Fiorelli, R. Gendelman, R. A. Morgan, P. Wingfield, and R. C. Gallo. 1993. Release, uptake, and effects of extracellular human immunodeficiency virus type I Tat protein on cell growth and viral transactivation. J. Virol. 67:277-287.

41. Barillari, G., R. Gendelman, R. C. Gallo, and B. Ensoli. 1993. The Tat protein of HIV-1, a growth factor for AIDS-Kaposi's sarcoma and cytokineactivated vascular cells, induces adhesion of the same cell types by using integrin receptors recognizing the RGD amino acid sequence. Proc. Natl. Acad. Sci. USA 90:7941-7945.

42. Albini, A., G. Barillari, R. C. Gallo, and B. Ensoli. 1995. Tat, the human immunodeficiency virus type I regulatory protein has angiogenic properties. Proc. Natl. Acad. Sci. USA. In press.

43. Brooks, P. C., R. A. F. Clark, and D. A. Cheresh. 1994. Requirement of vascular integrin $\alpha v \beta 3$ for angiogenesis. Science (Wash. DC). 264:569-571.

44. Najdi, M., A. R. Morales, J. Zigler-Weissman, and N. S. Pehneys. 1981 Kaposi's sarcoma: immunohistologic evidence for an endothelial origin. Arch. Pathol. Lab. Med. 105:274-275.

45. Guarda, L. G., E. G. Silva, N. G. Ordonez, and J. L. Smith. 1981. Factor VIII in Kaposi's sarcoma. Am. J. Clin. Pathol. 76:197-200.

46. Dorfman, R. F., and F. R. C. Path. 1984. The histogenesis of Kaposi's sarcoma. Lymphology. 17:76-77.

47. Beakstead, J. H., G. S. Wood, and V. Fletcher. 1985. Evidence of the origin of Kaposi's sarcoma from lymphatic endothelium. Am. J. Pathol. 119:294299.

48. Rutgers, J. L., R. Wieczorek, F. Bonetti, K. L. Kaplan, D. N. Posnett, A. E. Friedman-Kien, and D. M. Knowles. 1986. The expression of endothelial cell surface antigens by AIDS-associated Kaposi's sarcoma. Evidence for a vascular endothelial cell origin. Am. J. Pathol. 122:493-499.

49. Kraffert, C., L. Planus, and N. S. Penneys. 1991. Kaposi's sarcoma: further immunohistologic evidence of a vascular endothelial origin. Arch. Dermatol. 127:1734-1735.

50. Kourembanas, S., and D. V. Faller. 1989. Platelet-derived growth factor production by human umbilical vein endothelial cells is regulated by basic fibroblast growth factor. J. Biol. Chem. 264:4456-4459.

51. Yang, J., Y. Xu, C. Zhu, M. K. Hagan, T. Lawley, and M. K. Hoffermann. 
1994. Regulation of adhesion molecule expression in Kaposi's sarcoma cells. $J$. Immunol. 152:223-226.

52. Zhang, Y.-M., S. Bachmann, C. Hemmer, J. Van Lunzen, A. Von Stemm, P. Kern, M. Dietrich, R. Ziegler, R. Waldherr, and P. P. Nawroth. 1994. Vascula origin of Kaposi's sarcoma: Expression of leukocyte adhesion molecule-1, thrombomodulin, and tissue factor. Am. J. Pathol. 144:51-59.

53. Lampugnani, M. G., M. Resnati, M. Raiteri, R. Pigott, A. Pisacane, G Houen, L. P. Ruco, and E. Dejana. 1992. A novel endothelial-specific membrane protein is a marker of cell-cell contacts. J. Cell Biol. 118:1511-1522.

54. Wellicome, S. M., M. H. Thornhill, D. S. Thomas, J. S. S. Canchbury, G. S. Panayi, and D. O. Haskard. 1990. A monoclonal antibody that detects a novel antigen on endothelial cells that is induced by tumor necrosis factor, IL-1 or lypopolysaccharide. J. Immunol. 144:2558-2565.

55. Burgio, V. L., S. Zupo, S. Roncella, M. Zocchi, L. P. Ruco, and C. D. Baroni. 1994. Characterization of EN4 monoclonal antibody: a reagent with CD31 specificity. Clin. Exp. Immunol. 96:170-176.

56. Cotran, R, S., and J. S. Pober 1988. Endothelial activation: its role in inflammatory and immune reaction. In Endothelial Cell Biology. N. Simionescu and M. Simionescu, editors. Plenum Publishing, 335-347.

57. Pober, J. S. 1988. Cytokine-mediated activation of vascular endothelium Physiology and pathology. Am. J. Pathol. 133:426-433.

58. Scully, P. A., H. K. Steinman, C. Kennedy, K. Trueblood, D. M. Frisman, and J. R. Voland. 1988. AIDS-related Kaposi's sarcoma displays differential expression of endothelial surface antigens. Am. J. Pathol. 130:244-251.

59. Green, T. L., J. R. Meyer, T. E. Daniels, J. S. Greenspan, J. de Souza, and R. H. Kramer. 1988. Kaposi's sarcoma in AIDS: basement membrane and endothelial cell markers in late-stage lesions. J. Oral. Pathol. 17:266-272.

60. Modlin, R. L., F. M. Hofman, R. A. Kempf, C. R. Taylor, M. A. Conant, and T. H. Rea. 1983. Kaposi's sarcoma in homosexual men: an immunohistochemical study. J. Am. Acad. Dermatol. 8:620-627.

61. Tannenbaum, S. H., and H. R. Gralnick. 1990. Gamma-interferon modulates von Willebrand Factor release by cultured human endothelial cells. Blood 75:2177-2184.

62. Van der Poll, T., J. H. van Deventer, G. Pasterkamp, J. A. van Mourik H. R. Buller, and J. W. Cate. 1992. Tumor necrosis factor induces von Willebrand Factor release in healthy humans. Thromb. Haemostat. 67:623-626.

63. Janier, M., B. Flageul, L. Drouet, M. Scrobohaci, M. Villette, A. Palangie, and F. Cottenot. 1988. Cutaneous and plasma values of von Willebrand factor in AIDS: a marker of endothelial stimulation? J. Invest. Dermatol. 90:703-707.
64. Darzynkiewicz, Z. 1983. Molecular interactions and cellular change during the cell cycle. Pharmacol. Ther. 21:143-188.

65. Kaczmarek, L., and B. Kaminska. 1989. Molecular biology of cell activation. Exp. Cell Res. 183:24-35.

66. Pardee, A. B. 1989. G1 events and regulation of cell proliferation. Science (Wash. DC). 246:603-608.

67. Zetterberg, A. 1990. Control of mammalian cell proliferation. Curr. Opin. Cell Biol. 2:296-300.

68. Zetterberg, A., and O. Larsson. 1991. Coordination between cell growth and cell cycle transit in animal cells. Cold Spring Harbor Symposia on Quantitative Biology. Cold Spring Harbor Laboratory Press, Cold Spring Harbor, NY. $137-147$

69. Bybee, A., and N. S. Thomas. 1991. Cell cycle regulation. Blood Rev. 5:117-92.

70. Naeve, G. S., A. Sharma, and A. S. Lee. 1991. Temporal events regulating the early phases of the mammalian cell cycle. Curr. Opin. Cell Biol. 3:261-268.

71. Ensoli, B., and R. C. Gallo. 1994. Growth factors in AIDS-associated Kaposi's sarcoma: cytokines and HIV-1 Tat protein. AIDS Updates. 7:1-12.

72. Friesel, R., A. Komoriya, and T. Maciag. 1987. Inhibition of endothelial cell proliferation by gamma-interferon. J. Cell Biol. 104:689-696.

73. Cozzolino, F., M. Torcia, D. Aldinucci, and M. Ziche. 1990. Interleukin1 is an autocrine regulator of human endothelial cell growth. Proc. Natl. Acad. Sci. USA. 87:6487-6491.

74. Schneider, G., S. Gustincich, and G. Del Sal. 1991. The complexity of cell proliferation control in mammalian cells. Curr. Opin. Cell Biol. 3:276-281.

75. Clark, S. C., and R. Kamen. 1987. The human hematopoietic colony stimulating factor. Science (Wash. DC). 236:1229-1236.

76. Tamn, I. 1989. Il-6 current research and new questions. Ann. NY Acad. Sci. 557:478-489.

77. Pober, J. S., and R. S. Cotran. 1990. Cytokines and endothelial cell biology. Physiol. Rev. 70:427-451.

78. Kristensen, M. S., K. Paludan, C. G. Larsen, C. O. Zachariae, B. W Delevran, P. K. Jensen, P. Jorgensen, and K. Thestrup-Pedersen. 1991. Quantitative determination of IL- $1 \alpha$ induced IL-8 mRNA levels in cultured human keratypocytes, dermal fibroblast, endothelial cells, and monocytes. J. Invest. Dermatol. 97:506-510.

79. Winkles, J. A., and C. G. Gay. 1991. Serum, phorbol ester, and polypeptide mitogens increase class 1 and class 2 heparin binding (acidic and basic fibroblast) growth factor gene expression in human vascular smooth muscle cells. Cell Growth Differ. 2:531-540. 